\title{
DECOY ENFORCEMENT OF HOMOSEXUAL LAWS
}

Because the generally covert and consensual nature of homosexual offenses creates difficult enforcement problems, ${ }^{1}$ police in many cities ${ }^{2}$ use decoys to uncover male homosexual overtures in such public places as parks, transportation terminals, and rest rooms. ${ }^{3}$ These overtures are often so subtle that a casual observer could not recognize them. Indeed, in some cases the ability to recognize a veiled overture almost amounts to a "sixth sense." 4 The advance may start with a lingering or inquiring look, ${ }^{5}$ leading to innocent but exploratory conversation. ${ }^{6}$ The conversation may be tinged with suggestions of effeminacy ${ }^{7}$ in tone of voice, ${ }^{8}$ excessive lip and tongue movements, ${ }^{9}$ unusual use of superlatives, ${ }^{10}$ and overenunciation of

1 Even unwilling victims or participants are often reluctant to report the offense to the police. See Bowling, The Sex Offender and Laze Enforcement, Fed. Prob., Sept. 1950, pp. 11-14; cf. Goodsaid v. United States, 187 A.2d 486, 487 n.1 (D.C. Munic. Ct. App. 1963).

2 New York: see, e.g., People v. Feliciano, 10 Misc. 2d 836, 173 N.Y.S.2d 123 (Magis. Ct. 1958) ; Philadelphia: see Fonzi, The Furtive Fraternity, Greater Philadelphia, Dec. 1962, p. 20; University of $\mathrm{Pa}$. Institute of Legal Research \& University of Pa. Law Review, Field Study of Philadelphia Police Enforcement of Sex Crimes, 1961 (unpublished study financed by the Harrison Foundation, in University of $\mathrm{Pa}$. Law Review Library) [hereinafter cited as Field Study]; Pittsburgh: see Deutsch, The Trouble With Cops 76 (1955) ; District of Columbia: see, e.g., McDermett v. United States, 98 A.2d 287 (D.C. Munic. Ct. App. 1953).

3 Another possible means of deterring potential offenders might be the placement of conspicuously uniformed policemen in locations frequented by homosexuals. See Committee on Homosexual Offenses and Prostitution, Report, CMD. No. 247, at 78 (1957). However, this practice might cause homosexuals to seek new locations. Containment is a legitimate objective in police enforcement. See Helmer, Neze York's Middle Class Homosexuals, Harpers, March 1963, pp. 85, 86-87; Fonzi, supra note 2, at 52 .

The placement of spies at well-known locations is a third alternative. If the spy attempted to surprise the defendants while they were in the midst of their criminal behavior, this might present unlawful search problems. Compare Britt v. Superior Court, 58 Cal. 2d 480, 374 P.2d 817, 24 Cal. Rptr. 849 (1962) (enclosed toilet booth; unreasonable exploratory search), and Bielicki v. Superior Court, 57 Cal. 2d 602, 371 P.2d 288, 21 Cal. Rptr. 552 (1962) (same), and 63 ColvM. L. REv. 955 (1963), with People v. Young, 214 Cal. App. 2d 143, 29 Cal. Rptr. 492 (Dist. Ct. App. 1963) (toilet booth not enclosed), and People v. Norton, 209 Cal. App. 2d 176, 25 Cal. Rptr. 676 (Dist Ct. App. 1962) (same). Compare Goldman v. United States, 316 U.S. 129 (1942), with Silverman v. United States, 365 U.S. 505 (1961). More importantly, the spy would have a difficult task since homosexual overtures are often spoken quietly. If the defendants come to the location merely to meet each other and proceed elsewhere to pursue their objectives, the spy would have to follow them.

4 Stearn, The Sixth Man 55 (1961).

5 See Cory, The Homosexual in America 118 (2d ed. 1960); Henry, Sex VARIANTS 286 (1955); STEARN, op. cit. supra note 4, at 51, 59, 61; cf. WESTWOOD, A MrNority: A Report on the Life of the Homosexual in Great Britain 81-82, 84, 86 (1960).

${ }^{6}$ See Cory, op. cit. supra note 5 , at 117.

7 But cf. Ploscowe, SeX AND the LAW 196 (1951).

8 See CoRY, op. cit. supra note 5, at 117; HENRY, op. cit. supra note 5, at 291; STEARN, op. cit. sipra note 4 , at 47.

9 See HENRY, op. cit. supra note 5, at 286.

${ }^{10}$ Cf. WESTwOod, op. cit. supra note 5, at 84-85. 
particular syllables and words. Suggestion also may be conveyed by holding a cigarette in an effeminate way, ${ }^{11}$ affectation in hand movements, ${ }^{12}$ or a "middle-size enigmatic smile." 13 The use of conversational gambits, ${ }^{14}$ such as that the weather makes one feel "hot," 15 or words like "gay" or "straight" 16 provide additional clues. Ultimately, there may be an invitation to stop at a bar for a glass of beer ${ }^{17}$ and then to come to the apartment for a drink or "some fun." 18

Since the defendant's behavior may be too ambiguous to insure conviction for a particular homosexual offense, the decoy may try to elicit more overt conduct. The manner in which the decoy elicits that conduct is significant because his ability to secure convictions ${ }^{19}$ depends to a large extent upon the defenses which an accused may raise because of the decoy's behavior. Moreover, the decoy situation itself gives rise to slippery problems of proof when, as is often the case, only the communicants perceive the subtle interchange.

Since the status of being a homosexual is not itself criminal, prosecutions for homosexual acts must be conducted with particular caution:

The personal abhorrence upon the part of the court for the conduct attributed to the defendant . . . is altogether beside the point. ... [This] is a prosecution ... under a specific statute.

. . No conviction can be justified unless the facts fit into the statute. $^{20}$

The use of decoys complicates the problem further: "Cases of this nature have difficult and troubling aspects. They involve not only statutory construction, but also moral considerations, social interests, [and] police practices . . . ." 21

11 Cf. ibid.

12 See CORY, op. cit. supra note 5 , at 117 .

13 STEARN, op. cit. supra note 4, at 61.

14 Cf. Westwoon, op. cit. supra note 5 , at 84-85.

15 See CoRY, op. cit. supra note 5 , at 117.

16 CoRY, op. cit. supra note 5, at 108-09; cf. Field Study 8. Compare People v. Johnson, 99 Cal. App. 2d 559, 560-61, 222 P.2d 58, 60 (Dist. Ct. App. 1950) ("straight" is offer to buy or sell narcotics).

17 CoRY, op. cit. supra note 5, at 118 .

18 People v. Humphrey, 111 N.Y.S.2d 450, 452 (Broome County Ct. 1952) ; see King v. United States, 90 A.2d 229 (D.C. Munic. Ct. App. 1953) ; People v. Feliciano, 10 Misc. 2d 836, 173 N.Y.S.2d 123 (Magis. Ct. 1958); People v. Pleasant, 23 Misc. 367, 371, 122 N.Y.S.2d 141, 145 (Magis. Ct. 1953).

19 The use of decoys to harass homosexuals by threats of exposure or prosecution may make the homosexuals less likely to annoy strangers. Even though homosexuals who look for partners in public parks, restrooms, and transportation terminals are unlikely to have stable friendships with other homosexuals, see Helmer, supra note 3 , at 87 ; Field Study 37, they will, nevertheless, communicate their experiences with decoys, and many homosexuals may exercise restraint in approaching strangers in order to avoid decoys. See Watson, Psychiatry for Lawyers 73 (mimeo ed. 1957). 20 People v. Feliciano, 10 Misc. 2d 836, 839, 173 N.Y.S.2d 123, 126 (Magis. Ct. 1958); accord, People v. Humphrey, 111 N.Y.S.2d 450, 455 (Broome County Ct. 1952),

21 Henderson v. United States, 117 A.2d 456, 458 (D.C. Munic. Ct. App. 1955). 


\section{Conduct Necessary To Establish a Criminal HoMosexual OVERTURE}

The aggressiveness of conduct necessary to establish a particular homosexual offense determines the scope of the decoy's activity.

\section{A. Clear Communication of Willingness}

\section{Communication Offenses}

Many statutes proscribe sexually directed communications generally 22 or homosexual communications in particular ${ }^{23}$ by prohibition of soliciting, enticing, inviting, proposing, or inducing. Often these statutes do not limit the offense to public places, ${ }^{24}$ but seem to make the sexual communication unlawful because it indicates sufficient predisposition to commit a more consummate crime ${ }^{25}$ - such as sodomy. ${ }^{26}$

Although the word solicitation may connote importunity, ${ }^{2 \pi}$ courts generally have not required independent establishment of that concept, but recognize its presence in any clear communication of willingness to engage in prohibited conduct. ${ }^{28}$ Although close statutory construction is necessary in homosexual cases, the search for some separately identifiable element of importunity misconceives the application of the rule of strict construction by focusing only upon the dictionary meaning of one particular word without regard to the connotations suggested by the factual setting in which the

22 E.g., Cal. Pen. Code $\S \S 647$ (a), (d) ; N.J. Stat. Ann. $\$ 2 A: 170-5$ (1953). Many of these statutes use general language such as soliciting lewd or indecent acts. This language is intended to reach at least all otherwise unlawful sexual conduct, and is not void for vagueness. See State v. Milne, 187 A.2d 136, 138-41 (R.I. 1962), appeal dismissed, 373 U.S. 542 (1963).

23 HawaIr Rev. Laws \$314-2(g) (1955); New York PeN. Law \$722(8). Many statutes create an offense which rises to felony proportions. E.g., MrcH. Comp. Laws \$750.338 (Supp. 1956); PA. Stat. AnN. tit. 18, \$ 4502 (1963). (1953).

24 E.g., Ark. Stat. AnN. \$41-3202 (1957); Colo. Rev. Stat. Ann. §40-2-31

25 Sodomy may include any form of unnatural copulation, see, e.g., State v. Milne, 187 A.2d 136, $138-40$ (R.I. 1962), appeal dismissed, 373 U.S. 542 (1963) ; MrnN. STAT. ANN. \$617.14 (1947); OHIo Rev. Code ANN. \$2905.44 (Page 1954), or may be restricted to anal copulation only, see, e.g., Barton v. State, 79 Ga. App. 380, 53 S.E.2d 707 (1949); Commonwealth v. Poindexter, 133 Ky. 720, 118 S.W. 943 (1909); Prindle v. State, 31 Tex. Crim. 551, 21 S.W. 360 (1893). See generally Model Penal Code $\$ 207.5$, comment at 279 (Tent. Draft No. 4, 1955).

${ }^{26}$ Compare Wechsler, Jones \& Korn, The Treatment of Inchoate Crimes in the Model Penal Code of the American Laze Institute: Attempt, Solicitation, and Conspiracy, 61 Colum. L. Rev. 571, 572, 622, 627-28 (1961), zeith State v. Milne, supra note 25 , at 141 . However, soliciting lewdness statutes which derive from common law nuisance, e.g., ARK. STAT. ANN. \& 41-32-02 (1957), may be directed against the nuisance effect of the defendant's conduct upon actual or potential perceivers. Cf. Rittenour v. United States, 163 A.2d 558 (D.C. Munic. Ct. App. 1960) ; 70 YALE L.J. 623-25 (1961).

27 See Webster, Third New International Dictionary 2169 (1961).

28 The following cases deal with prostitutes and procurers: People v. Phillips, 70 Cal. App. 2d 449, 453-54, 160 P.2d 872, 874 (Dist. Ct. App. 1945) ; see State v. Render, 203 Iowa 329, 210 N.W. 911 (1927) ; cf. Golden v. United States, 167 A.2d 796 (D.C. Munic. Ct. App. 1961) ; Cunningham v. United States, 86 A.2d 918 (D.C. Munic. Ct. App. 1952) ; Curran v. United States, 52 A.2d 121 (D.C. Munic. Ct. App. 1947); Hall v. United States, 34 A.2d 631 (D.C. Munic. Ct. App. 1943). 
word must necessarily be applied. As in the case of prostitution, homosexual communications are often directed toward sympathetic recipients. Accordingly, any communication which expresses a willingness to engage in homosexual activity should constitute an offense under a statute concerned with a later, more consummate crime. Similarly, any clear communication of homosexual willingness should constitute a violation of a statute ${ }^{29}$ which is intended only to curtail the annoying effect of homosexual overtures upon the public. ${ }^{30}$

Most of the cases which show a possible application of this "willingness" standard to homosexual communications have been decided under the New York Penal Law section $722(8) .{ }^{31}$ Although this statute also requires loitering and provocation to a breach of the peace, the courts have treated the soliciting aspect as an independent element of the crime, ${ }^{32}$ and several courts have recognized in dictum that solicitations can occur in subtle ways. ${ }^{33}$ In addition, assertive conduct as well as mere use of words can constitute a solicitation. For example, in People v. Strauss, ${ }^{34}$ a person who touched the private parts of another man standing at an adjacent urinal was found to be soliciting. By way of contrast, in People v. Humphrey, ${ }^{35}$

29 Cal. Pen. Code $\$ \S 647$ (a), (d) ; Colo. Rev. Stat. Ann. $\$ 40-9-15$ (1953); An Act To Provide for the Treatment of Sexual Psychopaths in the District of Columbia, and for Other Purposes, ch. 428, \$102, 62 Stat. 346 (1948) (now D.C. CodE ANN. \$22-2701 (1961); GA. CODE ANN. \$26-6101 (1953); HAWAII REV. CODE \$ 314-2 (1955); N.Y. Pen. Law \$722(8); Moder Penat Code \$251.3 (Proposed Official Draft 1962); Model Penal Code \$207.5(4) (Tent. Draft No. 4, 1955).

30 See 70 YALE L.J. 623, 623-25 (1961).

31 Any person who with intent to provoke a breach of the peace, or whereby a breach of the peace thay be occasioned, commits any of the following acts shall be deemed to have committed the offense of disorderly conduct: . . .

8. Frequents or loiters about any public place soliciting men for the purpose of committing a crime against nature or other lewdness . . . .

N.Y. Pen. Law § 722(8) ; accord, HawaIr Rev. Laws § 314-2(g) (1955).

32 See People v. Evans, 19 Misc. $2 d$ 1071, 192 N.Y.S.2d 144 (Ct. Spec. Sess. 1959), rev'd without opinion, 7 N.Y.2d 1030,166 N.E.2d 861,200 N.Y.S.2d 72 (1960); People v. Feliciano, 10 Misc. 2d 836, 173 N.Y.S.2d 123 (Magis. Ct. 1958) ; People v. Burnes, 178 N.Y.S.2d 746 (Ct. Spec. Sess. 1958); People v. McCormack, 9 Misc. 2d 745, 169 N.Y.S.2d 139 (Ct. Spec. Sess. 1957) ; People v. Pleasant, 23 Misc. 2d 367, 122 N.Y.S.2d 141 (Magis. Ct. 1953) ; People v. Humphrey, 111 N.Y.S.2d 450 (Broome County Ct. 1952).

33 People v. Evans, supra note 32, at 1072, 192 N.Y.S.2d at $145-46$; People v. Burnes, supra note 32, at 749; People v. McCormack, supra note 32, at 747, 169 N.Y. S.2d at 142; People v. Pleasant, supra note 32, at 369-70, 122 N.Y.S.2d at 144.

34114 N.Y.S.2d 322 (Magis. Ct. 1952); cf. People v. Evans, 19 Misc. 2d 1071, 192 N.Y.S.2d 144 (Ct. Spec. Sess. 1959) (dictum).

35111 N.Y.S.2d 450 (Broome County Ct. 1952). The court refused to consider the defendant's conduct immediately prior and subsequent to the invitation for the purpose of clarifying the ambiguity. Id. at 454. However, in People v. Pleasant, 23 Misc. 2d 367, 122 N.Y.S.2d 141 (Magis. Ct. 1953), similar evidence may have been used for that purpose. When homosexual communications are proscribed because they are nuisances or tend to provoke breaches of the peace on the part of perceivers, the criminality of the communication is dependent upon whether it has such potential effects and should be determined solely by reference to the objective content and manner of the communication itself. And when the communication is proscribed because it is a step toward more consummate crime, surounding circumstances tending to show the defendant's intent should be taken into account. See King v. Cope, 16 Crim. App. R. 77 (Eng. 1921) ; cf. Wechsler, Jones \& Korn, supra note 26, at 627-28. 
the court held that defendant's invitation to a casual acquaintance to come to his apartment for some "beer, candy and fun" was too ambiguous, and in Commonvealth v. Yeager, ${ }^{36}$ decided under a Pennsylvania soliciting statute, ${ }^{37}$ the court held that a defendant who touched the exposed private parts of $A$ in the presence of $B$ did not solicit $B .^{38}$ Strauss, Humphrey, and $Y$ eager all seem to support the standard of a clear communication of willingness; in one the standard was met, while in the other two it was not.

Three other cases arising under section $722(8)$ seem to require an element of importunity in addition to willingness, but their reasoning is of limited applicability. People v. Feliciano ${ }^{38}$ held that a communication of willingness, so vivid that the court considered it too obscene for repetition, was not a solicitation because it was "casual, friendly conversation." 4" The court's concern with the necessity of finding a potential breach of the peace ${ }^{41}$ makes its analysis inapplicable to statutes not directed at breaches of the peace. In People v. Burnes ${ }^{42}$ and People v. McCormack, ${ }^{43}$ the defendants' conduct-going in and out of toilet booths in the first case and engaging in onanism while looking around and smiling in the second-was probably too ambiguous to constitute a clear manifestation of homosexual willingness, let alone a separately identifiable importunity. Therefore, despite these cases, behavior that clearly indicates willingness may be sufficient to constitute a homosexual communication offense under a statute directed at nuisances. In addition, even an ambiguous communication might be sufficient to support a conviction under a statute concerned with prevention of more consummate offenses if there was other evidence demonstrating the defendant's intention.44

\section{2. "Inchoate" Communication Offenses}

In addition to a clear communication of willingness, statutory proscriptions of soliciting, inviting, and enticing apparently require that the first homosexual communication come from the defendant. ${ }^{45}$ Initiating conduct is not as clearly required, however, by statutes which forbid loitering for the purpose of soliciting or engaging in perverted acts ${ }^{46}$ in order to prevent

36 21 Monroe Legal Rptr. 205 (Pa. Ct. Quarter Sess. 1958).

37 Pa. Stat. AnN. tit. 18, §4502 (1963).

3821 Monroe Legal Rptr. at 207.

3910 Misc. 2d 836, 173 N.Y.S.2d 123 (Magis. Ct. 1958).

40 Id. at 841,173 N.Y.S.2d at 127 (Magis. Ct. 1958).

41 Id. at 841,173 N.Y.S.2d at 128.

42178 N.Y.S.2d 746 (Ct. Spec. Sess. 1958).

439 Misc. 2d 745, 169 N.Y.S.2d 139 (Ct. Spec. Sess. 1957).

44 See note 35 supra.

45 See People v. Burnes, 178 N.Y.S.2d 746 (Ct. Spec. Sess. 1958) ; People v. McCormack, 9 Misc. 2d 745, 169 N.Y.S.2d 139 (Ct. Spec. Sess. 1957); cf. State v. Norris, 82 Ore. 680, 162 Pac. 859 (1917); Smith v. Mitchell, 64 Cal. App. 463, 467, 221 Pac. 964, 966 (Dist. Ct. App. 1923); Nash v. Douglass, 12 Ab. Pr. (n.s.) 187, 190 (Brooklyn, N.Y., City Ct. 1872).

46 Cal. Pen. Code \$647(d); Model Penal Code \$251.3 (Proposed Official Draft 1962) ; R.I. GEN. LAwS ANN. \$ 11-34-5 (1957). Criminality is also fixed at an early stage by D.C. CODE ANN. $\$ 22-2701$ (1961) ("address for the purpose of"). 
assemblages of homosexuals in public places. ${ }^{47}$ Although a defendant's initiating communication of willingness should satisfy these statutes, responsive conduct is inconclusive ${ }^{48}$ and should not support a conviction absent an outright confession of purpose. ${ }^{49}$

\section{Attempts}

Unlike nuisance and breach of the peace solicitations, the existence of an attempt is determined by its relation to the consummate crime, and not by a comparison of the conduct in question with normal behavior. Attempts are punished because they indicate an intention to commit a more consummate crime which may succeed in the future. ${ }^{50}$ However, in cases involving clear verbal propositions of intercourse to girls under the age of consent, courts have not followed this rationale, but have required further acts with intent to commit the consummate crime. ${ }^{51}$ Even overt acts have been held not to constitute attempts ${ }^{52}$ unless the actor, intending to commit the specific crime at the immediate time and place, indecently touched the victim ${ }^{53}$ or indecently exposed himself. ${ }^{54}$ The only case which held that a clear overture to sodomy was not an attempt did not consider the solicitation an overt act. ${ }^{55}$ Nevertheless, in one case solicitation to sodomy was held to be attempted sodomy when the defendant urged the solicitee to join in an offense to be committed almost as soon as the two of them could reach the appointed place. ${ }^{56}$ Under these circumstances, the solicitation is a substantial step toward the commission of the crime and is so strongly corroborative of the defendant's purpose and of his willingness to 683 (1963).

48 But cf., People v. Lynn, 307 N.Y. 683, 120 N.E.2d 855 (1954) (per curiam); People v. Hansuld, 114 N.Y.S.2d 243, 246-47 (Magis. Ct. 1952).

49 Responsive conduct may have probative weight if evidence of prior offenses is admissible. See text accompanying notes 177, 179-80 infra; Sherman v. United States, 356 U.S. 369, 375-76 (1958) ; 44 Iowa L. REv. 578, 586-87 (1959).

50 Wechsler, Jones \& Korn, sicpra note 26, at 572.

51 Cox v. People, 82 I11. 191 (1876) ; State v. Frazier, 53 Kan. 87, 90-91, 36 Pac. 58, 59 (1894) (dictum) (attempted rape, no discussion of facts); In the Matter of Lloyd, 51 Kan. 501, 502, 33 Pac. 307, 308 (1893) (same) ; Clinkscales v. State, 46 Okla. Crim. 29, 288 Pac. 348 (1930) (alternative holding) (court confused attempted rape with assault with intent to rape). Other cases have reached this result on the theory that a solicitation alone is never an attempt. State v. Roby, 194 Iowa 1032, 1042, 188 N.W. 709, 714 (1922) (dictum); State v. Harney, 101 Mo. 470, 14 S.W. 657 (1890) (defendant not only solicited but went with victim to the appointed place).

52 See Mullins v. Commonwealth, 174 Va. 477, 5 S.E.2d 491 (1939); Cromeans v. State, 59 Tex. Crim. 611, 613-14, 129 S.W. 1129, 1134-35 (1909).

53 Hutto v. State, 169 Ala. 19, 53 So. 809 (1910); State v. Smith, 14 Del. (9 Houst.) 588, 33 Atl. 441 (Ct. Gen. Sess. 1892) ; State v. Pepka, 72 S.D. 503, 37 N.W.2d 189 (1949); State v. Tomblin, 124 W. Va. 264, 20 S.E.2d 122 (1942).

54 Payne v. Commonwealth, 33 Ky. L. Rep. 229, 110 S.W. 311 (Ct. App. 1908). 55 State v. Bereman, 177 Kan. 141, 276 P.2d 364 (1954) (no facts stated in opinion).

56 King v. Barker, [1924] N.Z.L.R. 865 (Ct. App.). 
act that there can be little question about his dangerousness. ${ }^{57}$ Judicial reluctance to sustain an attempt conviction on ambiguous language ${ }^{58}$ might be overcome by requiring a clearer statement of purpose instead of having a blanket rule that solicitation does not constitute an attempt at sodomy. ${ }^{59}$ In fact, less clarity might be required for homosexual as opposed to heterosexual attempts, since homosexual overtures are seldom made to adult strangers without serious intent.

Since homosexual overtures are often directed to those who the actor thinks will be sympathetic, any clear communication of willingness should be sufficient without requiring a separately identifiable element of importunity. Perhaps the appointment of a place to perform the consummate offense is not even necessary; ${ }^{60}$ clear language should be sufficiently corroborative of purpose. Indeed, the defendant might not have a place available for the commission of the offense but might be waiting for the other person to suggest one. ${ }^{61}$

Since the danger at which the attempt statute is directed refers to the likelihood of future unlawful conduct of the same nature as that attempted, the solicitee who actively participates in the preparations to commit the consummate crime should also be guilty of an attempt. On the other hand, a willing solicitee's mere agreement to the proposals of the solicitor is too equivocal to indicate sufficient predisposition on his part to commit further unlawful acts.

\section{B. Importunity}

Another consideration underlying the proscription of homosexual communications is that they may tend to provoke breaches of the peace. Section 722(8) of the New York Penal Law expresses such a purpose. It provides:

Any person who with intent to provoke a breach of the peace, or whereby a breach of the peace may be occasioned, commits any of the following acts shall be deemed to have committed the offense of disorderly conduct: . . .

8. Frequents or loiters about any public place soliciting men for the purpose of committing a crime against nature or other lewdness .... ${ }^{62}$

67 Compare Moder Penat Code \$5.02, comment (Tent. Draft No. 10, 1960) zith id. \$5.01 and Wechsler, Jones \& Korn, supra note 26, at 572 .

58 Smith v. Commonwealth, $54 \mathrm{~Pa} .209$ (1867); King v. Moore, [1936] N.Z. L.R. 979 (Ct. App.).

59 See Moder Penal Code $\$ 5.02$, comment (Tent. Draft No. 10, 1960).

${ }^{60}$ But see Model Penal Code $\$ 5.01(2)$ (b) (Tent. Draft No. 10, 1960).

61 However, the requirement that there be an appointed place may protect the homosexual "phantasizer" who never intended to commit the offense, but who derives satisfaction from the solicitation alone. See Field Study 14; Commonwealth v. Krout, $17 \mathrm{~Pa}$. D. \& C.2d 795 (Quarter Sess. 1957). Of course, this kind of offender violates those statutes directed at the annoying aspects of homosexual overtures.

62 N.Y. PEN. LAW $\$ 722(8)$. 
Requiring an intent to provoke a breach of the peace seems unrealistic and superfluous, since no solicitor desires a disturbance. ${ }^{63}$ This requirement has been treated in various ways by the courts. Some have ignored it; ${ }^{64}$ some have presumed it, ${ }^{65}$ thereby rendering the breach of the peace language superfluous; and others inquire whether a given solicitation threatens a disturbance. ${ }^{66}$ If a court takes the third approach, a separately identifiable element of importunity or persistent urging appears necessary, since mere expressions of willingness are unlikely to provoke disruptive, retaliatory action. ${ }^{67}$

\section{Touchings and Threats Thereof}

Homosexual overtures may go beyond mere communications to proposed or actual touching. Touching might violate a nuisance-type statute directed at lewd acts in public places. ${ }^{68}$ Courts have aiso recognized that touchings can constitute an assault, ${ }^{68}$ since assault relates to both the psychic and the physical security of the victim. ${ }^{70}$ An offer to touch, as well as actual contact, subjects the victim to fear and humiliation. Moreover, although assault with intent to commit sodomy requires specific intent, ${ }^{\mathbf{7 1}}$ touchings or threats thereof might also constitute that offense since intent may be inferred from defendant's words and acts. ${ }^{72}$ However, if the de-

63 See People v. Evans, 19 Misc. 2d 1071, 192 N.Y.S.2d 144 (Ct. Spec. Sess. 1959), rev'd without opinion, 7 N.Y.2d 1030, 166 N.E.2d 861,200 N.Y.S.2d 72 (1960); People v. Feliciano, 10 Misc. 2d 836, 173 N.Y.S.2d 123 (Magis. Ct. 1958); cf. People v. Harrison, 11 Misc. $2 d$ 445, 447, 173 N.Y.S.2d 128, 131 (Magis. Ct. 1958).

64 See People v. Burnes, 178 N.Y.S.2d 746 (Ct. Spec. Sess. 1958) ; People v. McCormack, 9 Misc. 2d 745, 169 N.Y.S.2d 139 (Ct. Spec. Sess. 1957).

65 See People v. Pleasant, 23 Misc. 2d 367, 122 N.Y.S.2d 141 (Magis. Ct. 1953); People v. Humphrey, 111 N.Y.S.2d 450 (Broome County Ct. 1952).

${ }^{66}$ People v. Evans, 19 Misc. 2d 1071, 192 N.Y.S.2d 144 (Ct. Spec. Sess. 1959), rev'd without opinion, 7 N.Y.2d 1030 , 166 N.E.2d 861 , 200 N.Y.S.2d 72 (1960); People v. Feliciano, 10 Misc. 2d 836, 173 N.Y.S.2d 123 (Magis. Ct. 1958); People v. Strauss, 114 N.Y.S.2d 322 (Magis. Ct. 1952).

67 Breach of the peace in $\$ 722(8)$ means to provoke violent reaction or to disturb, embarrass, or alarm, rather than merely to annoy. Compare People v. Strauss, 114 N.Y.S.2d 322, 324 (Magis. Ct. 1955), with People v. Rabey, 48 N.Y.S.2d 937 (Broome County Ct. 1944) See People v. Harrison, 11 Misc. 2d 445, 447, 173 N.Y.S.2d 128, 131 (Magis. Ct. 1958).

68 Compare Schwartz, Morals Offenses and the Model Penal Code, 63 CouvM. L. Rev. 669, 671-72 (1963), weith Perkins, An Analysis of Assault and Attempts To Assault, 47 Minn. L. Rev. 71, 75, 88-89 (1962).

${ }^{69}$ See Guarro v. United States, 237 F.2d 578 (D.C. Cir. 1956) ; Goodman v. United States, 118 A.2d 517 (D.C. Munic. Ct. App. 1955); Henderson v. United States, 117 A.2d 456 (D.C. Munic. Ct. App. 1955) ; McDermett v. United States, 98 A.2d 287 (D.C. Munic. Ct. App. 1953); Dyson v. United States, 97 A.2d 135 (D.C. Munic. Ct. App. 1953) ; Levy v. State, 69 Ga. App. 265, 25 S.E.2d 153 (1943).

70 May, Law of Crimes 261 (4th ed. 1938) ; see Perkins, Criminal Law 673-74 (1957); Clark \& Marshali, Crimes 651 (6th ed. 1958).

71 Perkins, Criminal Law 674 (1957) ; 24 Tenn. L. Rev. 383 (1956) ; cf. May, op. cit. supra note 70 , at 190 .

72 However, if the charge is assault with intent to commit a felony which does not embrace all forms of homosexual intercourse, the defendant must specifically intend to commit the particular felony. See People v. Goldstein, $146 \mathrm{Cal}$. App. 2d 268, 274-75, 303 P.2d 892, 896 (Dist. Ct. App. 1956) (attempt to commit oral copulation); State v. Ficklin, 190 Wash. 168, 172, 67 P.2d 897, 899, aff'd on other grounds, 192 Wash. 575, 74 P.2d 187 (1937) (attempt to commit oral copulation). 
fendant makes adequately suggestive remarks and touches the private parts of the victim or threatens to do so, this should be sufficient to constitute an attempt. ${ }^{73}$ The addition of a touching would make out an even stronger case than would the solicitation alone.

\section{Defenses Arising From the Decoy Situation}

The subtle manner in which homosexual overtures are made and the need to clarify ambiguous approaches suggest that responsiveness on the part of the decoy is often necessary to secure conviction. Even if the decoy does nothing, the defendant may deny any wrong because policemen as decoys are not themselves harmed by the alleged criminal behavior; and when the police decoy acts affirmatively the defendant may claim that the decoy's activities contravene public policy.

\section{A. Lack of an Element of the Offense}

Although a particular criminal statute may explicitly describe the elements necessary to constitute the offense, the statute's purpose often determines the scope of the prohibited conduct.

\section{Apparent Consent}

\section{a. Assanlt}

In McDermett $v$. United States, ${ }^{74}$ the defendant committed an act of onanism in the men's room of a motion picture theatre and then began a conversation with a plainclothesman who had observed him. The officer left the men's room and waited outside the theatre for the defendant to appear. The officer then followed the defendant who resumed the conversation. The men circled three blocks while they talked. The officer informed the defendant that he was staying at a particular hotel, and as he entered, the defendant went with him. When the officer reached the men's room on the first floor and stood before a urinal, the defendant came alongside, began to masturbate, and then touched the officer's genitals. $^{75}$ In Guarro v. United States, ${ }^{76}$ the defendant and the plainclothesman also noticed each other in a motion picture theatre. Both went to the balcony where the officer looked at the defendant, left, and lounged on the stairs for three or four minutes with his coat open. The defendant approached and asked the officer why he was not watching the picture. When the officer replied that it was too noisy, the defendant touched his clothed private parts. ${ }^{77}$ The courts in both McDermett and Guarro re-

73 Colo. Rev. Stat. Ann. \$40-915 (1953); Ga. Code Ann. \$26-6101 (1953).

7498 A.2d 287 (D.C. Munic. Ct. App. 1953).

75 Id. at 288.

76237 F.2d 578 (D.C. Cir. 1956).

77 Id. at $581-82$. 
versed convictions because they found that the policemen had manifested consent by indicating a homosexual willingness. ${ }^{78}$

In $M c D e r m e t t$ and Guarro the courts assumed that lack of consent was necessary to establish the particular assaults, yet, like the usual assault statute, ${ }^{79}$ the statute in those cases made no reference to consent. ${ }^{80}$ Legislatures have adopted the common-law crime of assault without clarifying its precise limits, ${ }^{81}$ and have left to the courts the determination of the extent to which consent vitiates the offense. As the court's emphasis on apparent consent in Guarro ${ }^{82}$ suggests, in the absence of any superior societal interest ${ }^{83}$ the law is concerned primarily with the defendant's propensity to inflict harm upon the physical and psychic security of the public. ${ }^{84}$ If the defendant acts only when he reasonably believes the victim is willing, there is no propensity to inflict unwanted individual injury. ${ }^{85}$ However, courts have recognized a superior societal interest and have refused to permit consent to vitiate an assault when great violence ${ }^{86}$ or the presence of assembled crowds ${ }^{87}$ creates a breach of the peace risk, ${ }^{88}$ or when there is serious bodily harm. ${ }^{89}$ And in dictum one court declared that the defendant's conduct was so immoral that it ought to be punished

78 Id. at $581 ; 98$ A.2d at $289-90$.

79 E.g., PA. Stat. ANN. tit. 18, \$4708 (1945).

80 D.C. CODE ANN. $\$ 22-504$ (1961).

81 See Beausoliel v. United States, 107 F.2d 292, 295 (D.C. Cir. 1939). See generally Perkins, An Analysis of Assault and Attempts To Assault, 47 MINN. L. REv. 71 (1962).

82237 F.2d at 581-82.

83 See Hall, Strict or Liberal Construction of Penal Statutes, 48 HARv. L. REv. 748, 766 (1935)'; Hughes, Consent as a Defence in Criminal Law, 103 LAw J. 116 (1953); Hughes, Consent in Sexual Offense, 25 Modern L. Rev. 672 (1962); 33 CAN. B. REV. 88 (1955).

84 See Schwartz, supra note 68 , at 671-72.

85 There is a basis to believe the victim is willing only if the victim's conduct is unequivocal, since the misconstruction of equivocal but innocent conduct indicates the defendant's propensity to inflict unwanted injury.

${ }^{86}$ Queen v. Coney, 8 Q.B.D. 534, 548-49 (1882) (Stephen, J.) (alternative holding); see Commonwealth v. Colberg, 119 Mass. 350 (1876).

87 Queen v. Coney, supra note 86 , at 552, 553-54 (Hawkins, J.) ; see State v. Burnham, 56 Vt. 445,447 (1884).

88 See MaY, op. cit. supra note 70, at 252-53; MILIER, CRIMInal LAw 173 (1934); Perkins, Crimtinal Law 83 (1957); Hughes, Consent in Sexual Offenses, 25 ModerN L. REv. 672, 674, 676-77 (1962); Puttkammer, Consent in Criminal Assanlt, 19 ILL. L. Rev. 617 \& n.2 (1925). But see Champer v. State, 14 Ohio St. 437 (1863).

89 Commonwealth v. Farrell, 322 Mass. 606, 78 N.E.2d 697 (1948) ; King v. Donovan, [1934] 2 K.B. 498 (dictum); Queen v. Coney, 8 Q.B.D. 534, 548-49 (1882) (Stephen, J.) (alternative holding); PERKIns, CRIMINAL LAw 83 (1957); Hughes, supra note 88, at 674,676 . The emphasis on serious bodily harm may result from society's concern for the loss of the victim's services and the risk that the victim will become a public charge, fear that the actor may become addicted to his practice and attack those who do not consent, and lingering doubts that there was full and free consent. See Hughes, Morals and the Criminal Law, 71 Y ALE L.J. 662, 670-77 (1962). Another factor is paternalistic protection of the victim from his own indiscretions. See Hart, LAw, LIBERTY AND MORALITY 30-32 (1963); Beale, Consent in Criminal Laze, 8 Harv. L. REv. 317, 325 (1895). 
regardless of consent. ${ }^{90}$ The courts in $M c$ Dermett and Guarro did not find such a superior moral interest.

Had McDermett and Guarro been charged with assault with intent to commit sodomy, a different result might have been reached on the issue of consent. Arguably the legislative intent would be to reach sodomy at an earlier stage, and since consent is no defense to sodomy, it perhaps should not vitiate an assault which the legislature has linked to sodomy. ${ }^{91} \mathrm{How}-$ ever, this broad construction ${ }^{92}$ ignores the use in the statute of the word "assault" which includes in its legal definition lack of consent. ${ }^{93}$

\section{b. Nuisance Offenses}

Since statutes proscribing lewd acts in public places are intended to prevent nuisances to the public, a defendant might argue that he does not violate such a statute if he touches or makes gestures only at one whom he reasonably believes will not take offense. Nevertheless, the defendant's limited objective does not vitiate the offense because uninvolved third persons still might see the activity, ${ }^{94}$ and the defendant's choice of a public place for his actions displays indifference to possible unpleasantness he

90 See State v. Chicorelli, 129 Conn. 601, 30 A.2d 544 (1943) (dictum) ; cf. Devlin, The Enforcement of Morals, 45 Proceedings Brit. ACADEMY 129, 133-34 (1959):

Whether the consent of the victim to a crime shall be a defense is a question of morals. It cannot be a question of physical injury to society; that is impossible. Nor is it a question of shock, corruption or exploitation; everything may be in private. Nor can it be that the defendant is a dangerous man against whom the rest of the community must be protected; the defendant who acts on the victim's consent is no menace to others. It must be that this is wrong because it transgresses one of the standards of behavior or moral principles which society requires to be observed ....

01 Cf. State v. Roby, 194 Iowa 1032, 188 N.W. 709 (1922) (assault with intent to rape child incapable of consenting); People v. Lipski, 328 Mich. 194, 43 N.W.2d 325 (1959) (semble) (assault with intent to commit adultery); Liebscher v. State, 69 Neb. 395, 95 N.W. 870 (1903) (assuait with intent to rape child incapable of consent); People v. Gibson, 232 N.Y. 458, 134 N.E. 531 (1922) (alternative holding) ("lewd" assault on girl below age of consent for lewd fondling and carressing); Cromeans v. State, 59 Tex. Crim. 611, 613-14, 129 S.W. 1129, 1132-33 (1909) (same); Ross v. State, 16 Wyo. 285, 299, 93 Pac. 299, 303 (1907) (same); Regina v. B. \& L., 71 Weekly N. (N.S.W.) 138 (Crim. App. 1954) (statute explicitly making indecent assault a crime without regard to consent did not require that the prosecution prove compulsion, threats, or hostility) ; 4 WAYNe L. Rev. 175 (1958). But see People v. Dong Pok Yip, 164 Cal. 143, 127 Pac. 1031 (1912) (simple assault) ; People v. Hickey, 109 Cal. 275, 41 Pac. 1027 (1895) (same) ; cf. Taylor v. State, 214 Md. 156, 163, 164-68, 133 A.2d 414, 417, 418-19 (1957) (dissenting opinion) (assault with intent to commit sodomy); State v. Pickett, 11 Nev. 255 (1876) (assault with intent to rape child incapable of consent); Commonwealth v. Miller, $80 \mathrm{~Pa}$. Super. 309 (1923) (same); Hughes, Consent in Sexnal Offenses, 25 MODERN L. Rev. 672, 677 n.18 (1962).

$92 \mathrm{~A}$ broad construction of an assault with intent statute is more reasonable when the legislature links assault to a particular felony, as in a statute proscribing assault with intent to commit sodomy, than when it generally proscribes assault with intent to commit a felony, and declares sodomy or the like a felony in another statute. Compare Ala. Code tit. 14, § 38 (1940) and CaL. Pen. Code $\$ 220$ with Mich. Comp. LAwS \$750.87 (1948).

93 However, if the legislature specifically condemns homosexual touchings, see ARIz. Rev. Stat. ANN. \$13-652 (1956); Mrch. Comp. Laws $\$ 750.338$ (1948), it is easier to hold that consent is no defense even if the legislature has not specifically declared consent irrelevant.

94 See 70 YALE L.J. 623, 624 \& n.11 (1961). 
might cause others. The same reasoning does not necessarily apply to verbal communications, since there is less risk that unintended persons will overhear subdued conversation. ${ }^{95}$ In these cases the courts should evaluate the risk in each case, unless the statute prohibits loitering ${ }^{96}$ and thereby seeks to protect the public against the visually annoying aspect of assemblages of homosexuals. ${ }^{97}$

\section{c. Breaches of the Peace}

The breach of the peace language in section 722(8) of the New York Penal Law ${ }^{98}$ has been interpreted to require solicitations which cause or have a tendency to cause violent reactions on the part of the person to whom the solicitation is addressed.99 Therefore, if the defendant acts only when the decoy has led him reasonably to believe that there is consent, his conduct neither indicates a propensity to disturb others in the future, nor constitutes a breach of the peace, since the officer's duty is to arrest the defendant rather than to retaliate physically. ${ }^{100}$ However, if this statute also covers conduct which might provoke breaches of the peace on the part of third party observers, its applicability to a consensual situation is similar to that of the nuisance solicitation statute. A distinction should then be drawn between communications which contain a risk of being witnessed by third parties, such as physical touchings, and those which contain virtually no risk, such as subdued conversation.

\section{The Decoy as "Victim"}

Although the decoy's consent may take the defendant's conduct out of the reach of a particular statute, the mere fact that the victim is a decoy should not have a similar effect since it is unrelated to the dangerousness of the defendant.

Section 722(8) of the New York Penal Law prohibits soliciting "whereby a breach of the peace may be occasioned." 101 In People v. Pleasant, a magistrates' court held that since this language referred to

95 See Morris v. District of Columbia, 31 A.2d 652 (D.C. Munic. Ct. App. 1943) (semble) (previous acquaintance between parties relevant); People v. Yergan, 164 Misc. 83, 299 N.Y. Supp. 248 (Magis. Ct. 1937) (dictum) (same); ModeI PeNAL CoDE \$251.3, status note (Proposed Official Draft 1962). Cf. People v. Feliciano, 10 Misc. 2d 836, 841, 173 N.Y.S.2d 123, 128 (Magis. Ct. 1958) (alternative holding); People v. Harrison, 11 Misc. 2d 445, 448, 173 N.Y.S.2d 128, 130-31 (Magis. Ct. 1958)' Compare Horton v. Mead, [1913] 1 K.B. 154.

96 Cal. Pen. Code $\$ 647$ (d); R.I. Gen. Laws ANn. \$11-34-5 (1956); Model Penal Code \$251.3 (Proposed Official Draft 1962); Model Penal Code §207.5 (4) (Tent. Draft No. 4, 1955).

97 Schwartz, Morals Offenses and the Model Pental Code, 63 Corvm. L. Rev. 669,675 (1963); see Model Penal Code $\$ 251.3$, status note at 237 (Proposed Official Draft 1962).

98 See text accompanying note 62 supra.

99 See note 63 supra and accompanying text.

100 Cf. People v. Feliciano, 10 Misc. 2d 836, 173 N.Y.S.2d 123 (Magis. Ct. 1958).

$101 \mathrm{Cf}$. text accompanying notes $63-67$ supra. 
behavior which tends to cause a breach of the peace, the fact that the solicitation had been addressed to a plainclothesman was irrelevant. ${ }^{102}$ However, in People v. Feliciano another magistrates' court decided that there could be no breach of the peace because the police officer to whom defendant addressed the solicitation had a duty to maintain the public order. ${ }^{103}$ Yet, it is defendant's conduct and the reaction of the ordinary person which should be determinative of any tendency to provoke a breach of the peace, not the reaction of a decoy-"victim."

A municipal court in the District of Columbia construing an assault statute reached a conclusion similar to Pleasant. In Dyson v. United States, ${ }^{104}$ the defendant touched the clothed private parts of a plainclothesman. The court recognized that this conduct was an assault if the victim suffered fear, shame, or humiliation, ${ }^{105}$ but the defendant claimed that the victim suffered no injury because he was a case-hardened police officer who had occasion to deal with sexual perverts. ${ }^{106}$ The court held that the victim's identity as a police officer was irrelevant, since the defendant did not know it at the time of the offense, and the same act when directed at the ordinary person would arouse fear, shame, or humiliation. ${ }^{107}$ This rationale is also applicable to offenses under statutes which prohibit communications in order to avoid public nuisances. Similarly, in attempts and in communication offenses in which the legislative purpose is to punish those with a propensity to commit more consummate crime, the fact that the victim's identity prevents completion of the attempt has no bearing on defendant's chances of future success. ${ }^{108}$

10223 Misc. 2d 367, 371-72, 122 N.Y.S.2d 141, 144 (Magis. Ct. 1953).

103 People v. Feliciano, 10 Misc. 2d 836, 173 N.Y.S.2d 123 (Magis. Ct. 1953) (alternative holding).

10497 A.2d 135 (D.C. Munic. Ct. App. 1953).

105 Id. at 136; accord, Beausoliel v. United States, 107 F.2d 292 (D.C. Cir. 1939); Clancy v. State, 93 Tex. Crim. 380, 247 S.W. 865 (1923); Hawes v. State, 44 S.W. 1094 (Tex. Crim. App. 1898); Model Penal Code \$207.6, comment at 292 (Tent. Draft No. 4, 1955); Perkins, CRIMINaI LAW 80 (1957).

106 Accord, McKenna, Criminal Law, 29 N.Y.U.L. Rev. 141, 144-45 (1954).

10797 A.2d at 136-37; accord, Guarro v. United States, 237 F.2d 578, 580-81 (D.C. Cir. 1956).

108 Traditionally, the law has distinguished between attempts which are legally impossible and those which are factually impossible. The former vitiates the attempt and the latter does not. See, e.g., Perkins, Criminal Law 494 (1957). Legal impossibility occurs when the defendant's ultimate objective, if completed, would not have constituted a crime, even though he thought that it would. Factual impossibility occurs when the purpose of the defendant to accomplish a crime becomes frustrated by some extrinsic circumstance unknown to him. See, e.g., Smith, Two Problems in Criminal Attempts Re-examined, 1962 CRIM. L. REv. (Eng.) 212-22. In decoy cases, factual impossibility results when a decoy, who purports to go along with the defendant, never really intends to consummate the crime. The extrinsic circumstance is the unwillingness of the decoy. See People v. Gardner, 144 N.Y. 119, 38 N.E. 1003 (1894); cf. State v. Mandel, 78 Ariz. 226, 278 P.2d 413 (1954); People v. Siu, 126 Cal. App. 2d 41, 271 P.2d 575 (Dist. Ct. App. 1954); People v. Lanzit, 70 Cal. App. 498, 233 Pac. 816 (Dist. Ct. App. 1925); People v. Heinrich, 65 Cal. App. 510, 224 Pac. 466 (Dist. Ct. App. 1924). The legal-factual impossibility analysis overlooks the actor's own mental frame of reference, which is the most relevant indicator of his dangerous potential. See Wechsler, Jones \& Korn, The Treatment of Inchoate Crimes in the Model Penal Code of the American Law Institute: Attempt, Solicitation, and Conspiracy, 61 Coluar. L. REv. 571, 578-79 (1961). 


\section{B. Entrapment}

In other areas in which decoys have been used, the prosecution may prove every element of the offense charged, and yet the decoy's conduct may prevent conviction because it constitutes an entrapment. The doctrine of entrapment reflects a policy that the powers of government should not be used to instigate otherwise innocent persons to commit crimes which they would not commit on their own. ${ }^{109}$ These persons are situational rather than chronic offenders. ${ }^{110}$ Courts classically implement the entrapment policy by ascertaining, in each instance, the defendant's "predisposition" to commit the offense and the degree of persuasion or enticement offered by the decoy. ${ }^{111}$

These criteria of entrapment suggest the necessity to examine the conduct of both the decoy and the defendant to determine whether the offense was the "product of the creative activity" 112 of the police. The defendant's prior record of convictions and his bad reputation are relevant factors in this examination. ${ }^{113}$ Even if the police activity excessively induced the defendant, he will not be exonerated if the prosecution can show a predisposition to commit the crime. ${ }^{114}$ However, bad reputation evidence to establish predisposition has been challenged as unreliable, ${ }^{115}$ and the admissibility of both bad reputation evidence and prior offenses involves a risk that the jury will convict the defendant on the basis of his former behavior. ${ }^{116}$

Although in some areas courts have treated the defendant's reactions to the decoy's suggestions as indicative of whether the defendant was

109 See, e.g., Sorrells v. United States, 287 U.S. 435, 448 (1932). Sherman v. United States, 356 U.S. 369 (1958).

110 Donnelly, Judicial Control of Informants, Spies, Stool Pigeons and Agents Provocateurs, 60 YAle L.J. 1091, 1113 (1951).

111 See, e.g., Sherman v. United States, 356 U.S. 369, 373 (1958).

112 Sorrells v. United States, 287 U.S. 435, 451 (1932).

113 Donnelly, supra note 110 , at 1102 . Reputation evidence is generally allowed on the theory that it establishes reasonable grounds for the policemen's suspicion. See, e.g., Whiting v. United States, 296 F.2d 512 (1st Cir. 1961); Heath v. United States, 169 F.2d 1007, 1010 (10th Cir. 1948); Fisk v. United States, 279 Fed. 12, 17-18 (6th Cir. 1922). Contra, United States v.'Washington, 20 F.2d 160, 162 (D. Neb. 1927) (dictum).

114 See, e.g., Sorrells v. United States, 287 U.S. 435, 451 (1932).

115 See 51 Geo. L.J. 190, 195 (1962). Courts are beginning to circumscribe the admissibility of reputation evidence. See United States v. Collier, 317 F.2d 157 (7th Cir. 1963) (general reputation inadmissible); cf. Hansford v. United States, 303 F.2d 219 (D.C. Cir. 1962) (uncorroborated police testimony of alleged prior offense).

116 Sherman v. United States, 356 U.S. 369, 382-83 (1958) (concurring opinion); Hansford v. United States, 303 F.2d 219, 223-24 (D.C. Cir. 1962) (dictum); Note, 73 HARv. L. Rev. 1333, 1339 (1960); 33 N.Y.U.L. Rev. 1033, 1038 (1958); 70 YalE L.J. 623, 633-34 (1961). Removal of the entire question from the jury might alleviate the underlying problem. See Cowen, The Entrapment Doctrine in the Federal Conts, and Some State Court Comparisons, 49 J. CrrM. L., C. \& P.S. 447, $452-53$ (1959).

Some courts, however, in cases involving sex crimes, have permitted the prosecution to introduce evidence of prior similar crimes or acts to show the probability that the defendant committed the crime. See, e.g. State v. McDaniel, 80 Ariz. 381, 388, 298 P.2d 798, 802 (1956) (alternative holding); Dyson v. United States, 97 A.2d 135 (D.C. Munic. Ct. App. 1953) ; Commonwealth v. Kline, 361 Pa. 434, 65 A.2d 348 
"otherwise innocent," 117 this criterion does not help to distinguish the situational from the chronic homosexual offender. The former may eagerly accede during a period of emotional stress, ${ }^{118}$ whereas the latter may show reluctance due to his greater wariness of "hustlers" who may beat and rob him, blackmailers, and police decoys. ${ }^{119}$ Furthermore, any nervousness in the defendant may be due either to the sexual excitement of the experienced offender or to the unfamiliarity and hesitancy of the novice. ${ }^{120}$

Similar difficulties invalidate the usual criterion used to determine whether police enticement was a catalyst to an "otherwise innocent" defendant. Ordinarily any appeal based on incentives other than pecuniary gain will lure the situational rather than the chronic offender. ${ }^{121}$ This criterion is inapplicable in homosexual offenses since both chronic and situational offenders act upon easily tempted impulses.122 The uncontrollable quality of the homosexual impulse suggests a special standard for evaluating police conduct in that context. If the policeman initially encouraged the defendant by a clear expression of willingness, ${ }^{123}$ since this encouragement is an improper inducement, the prosecution should have to overcome ${ }^{124}$ the entrapment defense by proof that the defendant's

(1949). But see, e.g., State v. Atkinson, 293 S.W.2d 941 (Mo. 1956) ; State v. Start, 65 Ore. 178, 132 Pac. 512 (1913); Young v. State, 159 Tex. Crim. 164, 261 S.W.2d 836 (1953). This approach is opposed to the traditional view that the probable prejudicial effect outweighs the aid to conviction. See McCormrck, EvIDENCE \$157, at 327 (1954). See generally Trautman, Logical or Legal Relevancy-A Conflict in Theory, 5 VAND. L. Rev. 385, 408-09 (1952); Note, 40 MINn. L. REv. 694 (1956); 39 Calif. L. Rev. 584 (1951); 23 TEMP. L.Q. 133 (1949); 98 U. PA. L. Rev. 116 (1949); 9 WASH. \& LeE L. Rev. 86 (1952).

117 See United States v. Masciale, 236 F.2d 601 (2d Cir. 1956), aff'd, 356 U.S. 386 (1958) ; People v. Head, 208 Cal. App. 2d 399, 25 Cal. Rptr. 124, 128 (Dist. Ct. App. 1962); People v. Williams, 237 N.Y.S.2d 527, 534 (Oneida County Ct. 1963).

11870 Y ALE L.J. 623, 633 (1961).

119 Id. at 633.

120 Ibid.

121 United States v. Washington, 20 F.2d 160, 163 (D. Neb. 1927) (dictum); Note, 73 Harv. L. REv. 1333, 1335-36 (1960); 70 YALE L.J. 623, 633 (1961); see Note, 31 St. Jorn's L. Rev. 262, 265 (1957).

12270 Yale L.J. 623, 633 \& n.81 (1961) ; see Homosexuatity, A Cross-Cultural Approach 400 (Corey ed. 1956); Ploscowe, SEX AND the LaW 212-13 (1951); cf. Johnson v. United States, 317 F.2d 127 (D.C. Cir. 1963) (defendant entitled to submit entrapment to jury when he might have been motivated by the hope of a reward of narcotics); United States v. Silva, 180 F. Supp. 557 (S.D.N.Y. 1959) (by implication) (excessive inducement to offer drugs to addict in great physical need); United States v. Echols, 253 Fed. 862 (S.D. Tex. 1918) (any offer to intoxicated defendant is entrapment per se); People v. Hall, 25 I1l. 2d 297, 301, 185 N.E.2d 143, 145 (1962) (dictum) (offer of drugs to addict in great physical need); People v. Gallagher, 107 Cal. App. 425, 290 Pac. 504 (Dist. Ct. App. 1930) (semble) (addict accused of buying small quantity of narcotics entitled to entrapment instruction even though informer's persuasion was slight).

123 See 70 YALE L.J. 623, 634 (1961).

124 The defendant has the burden of persuasion that there was an improper inducement. Gorin v. United States, 313 F.2d 641, 652-54 (1st Cir. 1963) ; Note, 73 HARv. L. Rev. 1333, 1344 (1960); see United States v. Sherman, 200 F.2d 880, 882-83 (2d Cir. 1952); United States v. Markham, 191 F.2d 936, 937-38 (7th Cir. 1951) ; People 
conduct immediately preceding the inducement indicated willingness to commit the offense regardless of the decoy's conduct.

An alternative entrapment formula was advocated in the separate opinion in Sorrells $v$. United States ${ }^{125}$ and repeated in the concurring opinion in Sherman v. United States. ${ }^{126}$ This formula states that courts should not sanction police practices which fall beneath the "standards, to which common feelings respond, for the proper use of governmental power." Accordingly, the focus is upon the practices of the police and not upon the status of the defendant; the result is a prophylactic rule which exonerates the defendant regardless of whether the defendant's history or reaction to the enticement shows a predisposition to commit the crime. ${ }^{127}$ The sole inquiry is whether the particular police conduct would induce only those likely to commit the crime on their own, and the setting in which the inducement took place becomes highly significant. ${ }^{128}$ If this standard were applied to the homosexual decoy case, activity or passivity of the police officer would be the criterion since any initiating encouragement creates substantial risks of inducing the situational offender. ${ }^{128}$ However, the officer's activity would be judged in light of the defendant's im-

v. Benson, 206 Cal. App. 2d 519, 532, 23 Cal. Rptr. 908, 916 (Dist. Ct. App. 1962), cert. denied, 374 U.S. 806 (1963) ; People v. Grijalva, 48 Cal. App. 2d 690, 694, 121 P.2d 32, 34 (Dist. Ct. App. 1941); People v. Lee, 9 Cal. App. 2d 99, 109-10, 48 P.2d 1003, 1007-08 (Dist. Ct. App. 1935); Model PeNAL CoDe $\$ 2.10$, comment at 20-21 (Tent. Draft No. 9, 1959). But see Ryles v. United States, 183 F.2d 944, 945-46 (10th Cir. 1950). If the defendant meets this burden, entrapment is established unless the prosecution is able to show that the defendant was predisposed to commit the crime. Note, 73 HaRv. L. REv. 1333, 1344 (1960); see Gorin v. United States, supra at 652-54; United States v. Sherman, supra at 882-83.

125287 U.S. 435, 453 (1932) (separate opinion).

126356 U.S. 369, 382 (1958) (Frankfurter, J., concurring). Although no court has adopted this formula in an actual holding, some have suggested a preference for it. See Hansford v. United States, 303 F.2d 219 (D.C. Cir. 1962); McDermett v. United States, 98 A.2d 287, 290 \& n.6 (D.C. Munic. Ct. App. 1953); cf. United States v. Millpax, Inc., 313 F.2d 152 (7th Cir. 1963); Williamson v. United States, 311 F.2d 441 (5th Cir. 1962). See generally MODEL PeNAL CoDE $\$ 2.10(2)$, comment at 20 (Tent. Draft No. 9, 1959); Donnelly, supra note 110, at 1114; Comment, 9 Sw. L.J. 456,460 (1955).

127 See Sherman v. United States, 356 U.S. 369, 378, 382-83 (1958) (concurring opinion); Sorrells v. United States, 287 U.S. 435, 458-59 (1932) (separate opinion); Moder Penal Code $\$ 2.10$, comment at 19-20 (Tent. Draft No. 9, 1959).

128 Sherman v. United States, 356 U.S. 369, 378, 382-83 (1958) (concurring opinion). Under this formulation, entrapment is generally a question for the judge, since the court must preserve its processes from abuse. Id. at 385 (concurring opinion); Sorrells v. United States, 287 U.S. 435, 453, 457-58 (1932) (separate opinion); Cowan, The Doctrine of Entrapment in the Federal Courts, and Some State Court Comparisons, 49 J. CRIM. L., C. \& P.S. 447, 452-53 (1959); Moded PENAL Code \$2.10, comment at 21-22 (Tent. Draft No. 9, 1959) ; see Williams, The Defense of Entrapment and Related Problems in Criminal Prosecution, 28 FoRD. L. REv. 399, 416-17 (1959). The court must also provide a guide for police conduct. Cowan, supra at 452-53. However, the Model Penal Code suggests that the issue should be tried before a jury because it involves a determination of what might be too great a temptation for the ordinary citizen. MODEL PeNal Code $\$ 2.10$, comment at 22 (Tent. Draft No. 9, 1959). This consideration is not applicable to homosexual offenses, since the jury would not know what temptations are too great for the ordinary situational offender in this area.

129 See 70 YALE L.J. 623, 634 \& n.90 (1961). 
mediately preceding conduct since that would be part of the setting in which the inducement took place. ${ }^{130}$

Since the general standard for an improper inducement under either entrapment formula is the extent of the police officer's conduct expressing willingness to engage in homosexual activity, the accused has a defense if the officer consented to the solicitation of assault, or if the conduct of the accused lacked the necessary quality required to constitute a solicitation, attempt, or nuisance. However, entrapment is less helpful to the defendant than a claim that a necessary element of the offense is lacking because he must bear the burden of persuasion as to the improper inducement, whereas initiative and unequivocal conduct, lack of consent, and improper purpose are part of the prosecution's burden of persuasion. ${ }^{131}$

When police decoys are used in homosexual overture cases, the defendant's propensity to injure or disturb unwilling persons is the most significant factor regardless of whether the defense is consent or entrapment. However, the identity of the defense determines what conduct is relevant to evaluate that propensity. The classic entrapment formula considers the conduct of both the policeman and the defendant during the episode, and the defendant's prior history, but the prophylactic entrapment rule and the consent defense consider only the immediate conduct of the policeman, and exclude the defendant's reaction to the police officer's inducement or consent. However, the consent defenses in Guarro and $M c D e r m e t t$ present the question of whether consent exonerates the defendant whenever the police officer demonstrates willingness prior to the defendant's criminal act even if the defendant's conduct indicates that he would, in any event, have engaged in the criminal acts. In this situation the decoy's willingness is fortuitous, and the defendant has shown a propensity to injure or disturb unwilling persons. Therefore, the consent defense should not apply if the defendant's conduct indicated that he would commit the offense regardless of the other party's willingness. ${ }^{132}$

\section{Problems of Proof}

\section{A. The Need for Special Caution}

The court in Kelly $v$. United States ${ }^{133}$ considered extensively the practical problems of proof in homosexual decoy cases. Defendant had been tried before a judge sitting without a jury and convicted of violating

130 See State v. Burnette, 242 N.C. 164, 87 S.E.2d 191 (1955); Ditton v. State, 222 Ind. 25, 51 N.E.2d 356 (1943) ; People v. Spaulding, 81 Cal. App. 615, 254 Pac. 614 (Dist. Ct. App. 1927).

131 See Guarro v. United States, 237 F.2d 578, 581 (D.C. Cir. 1956) ; McDermett v. United States, 98 A.2d 287, 290 (D.C. Munic. Ct. App. 1953); Commonwealth v. Shrodes, $354 \mathrm{~Pa} .70,74,46$ A.2d 483, 486 (1946).

If the courts continue to follow the classic entrapment formula, then a claim of entrapment opens the door for evidence harmful to the defendant which might not otherwise be admissible.

132 See 34 N.C.L. REv. 536, 541-45 (1956).

133194 F.2d 150 (D.C. Cir. 1952). 
a "lewd invitation" statute. ${ }^{134}$ Although it was clear that on the evening in question he conversed with a plainclothesman in a downtown park and invited the plainclothesman to his apartment, the crucial issue in the case was whether defendant had in fact proposed that they go to his apartment for an act of perversion.135 The only support for the charge was the testimony of the decoy policeman. ${ }^{\mathbf{1 3 6}}$ The Court of Appeals for the District of Columbia Circuit recognized that particular care was required for the protection of the defendant because of the ease with which the accusation could be made, the difficulty to disprove it, potential blackmail, and the injury to the reputation of a person subjected to such an accusation. ${ }^{137}$ At the same time, the court was reluctant to impose rigid requirements of proof which would make prosecutions under the statute virtually impossible. ${ }^{138}$ Accordingly, it "counseled" the trial courts in terms of three governing considerations. "[T] he testimony of a single witness to a verbal invitation to sodomy should be received and considered with great caution ...." in order "that there be a known strictness . . . which will serve to deter prosecutors in dubious cases." In addition, evidence of defendant's good character which may tend to disprove homosexuality is important since it may be the only defense other than the defendant's own testimony, and may generate a reasonable doubt as to defendant's guilt. Moreover, corroboration should be necessary to establish the surrounding circumstances, "such as presence at the alleged time and place." ${ }^{138}$ The court then reversed the conviction for insufficient evidence. 140

In subsequent cases, District of Columbia courts suggest that perhaps the sodomitical nature of the offense rather than the use of police decoys gave rise to the Kelly "counsels." In two cases the municipal court of appeals has held that Kelly does not apply to decoy enforcement of the offense of soliciting prostitution. ${ }^{141}$ But the counsels have been applied

134 "It shall not be lawful for any person to invite, entice, persuade, or to address for the purpose of inviting, enticing or persuading any person . . . to accompany ... him or her . . . for the purpose of prostitution, or any other immoral or lewd purpose . . An Act To Provide for the Treatment of Sexual Psychopaths in the District of Columbia, and for Other Purposes, ch. 428, \$102, 62 Stat. 346 (1948) now D.C. CODE ANN. \$22-2701 (1961)).

135194 F.2d at 15I-52, 155.

136 Ibid.

137 Id. at 154-55.

138 Id. at 154.

139 Id. at 154-55. Compare CAL. PEN. CODE $\$ 653(\mathfrak{f})$ (corroboration required in prosecution for criminal solicitations); HAwAII REV. LAws $\$ \$ 248-49$ (1955) (same).

140 Compare Brenke v. United States, 78 A.2d 677 (D.C. Munic. Ct. App. 1951) (facts similar to Kelly; trier of fact can always believe prosecuting witness rather than accused).

141 Parker v. United States, 143 A.2d 98 (D.C. Munic. Ct. App. 1958) ; Price v. United States, 135 A.2d 854 (D.C. Munic. Ct. App. 1957). Kelly has been held inapplicable in nonhomosexual and nonsodomitical cases when no decoy was used. See McGhee v. District of Columbia, 137 A.2d 721 (D.C. Munic. Ct. App. 1958) (masturbation) ; Ingram v. United States, 110 A.2d 693 (D.C. Munic. Ct. App. 1955) (simple assault with heterosexual background). Although some cases imply that Kelly applies to heterosexual offenses, they do so under limited circumstances. In Goodsaid v. District of Columbia, 187 A.2d 486 (D.C. Munic. Ct. App. 1963), the 
to cases of homosexual attempts, ${ }^{142}$ proposals, ${ }^{143}$ and assaults ${ }^{144}$ when no decoy was used, as well as to homosexual invitations to ${ }^{145}$ and assaults upon decoys.146 However the Court of Appeals for the District of Columbia Circuit in Kelly itself and in Guarro v. United States ${ }^{147}$ applied the counsels when the sole witness to the alleged criminal act was a decoy. ${ }^{148}$ Moreover, in Goodsaid $v$. District of Columbia, ${ }^{149}$ the municipal court of appeals was more willing to credit the testimony of a complainant who "was not a plainclothes officer on the lookout to 'make a case." " 150

Other courts have been reluctant to require corroboration in sodomy cases for the testimony of a complaining witness ${ }^{151}$ or observing police officer, ${ }^{152}$ yet Kelly requires caution rather than rigid corroboration ${ }^{153}$ and applies to those offenses which are rarely seen by anyone except the

court applied Kelly to a situation in which a taxi driver was accused of making a lewd proposal to his female passenger. The same situation occurred in Coleman v. Godsey, 249 F.2d 522 (D.C. Cir. 1957) (per curiam) (appeal from revocation of taxi driver's license; Kelly-type analysis applied without citing Kelly). These cases may have taken into account the special susceptibility of taxi drivers to charges of this sort. In Wilson v. United States, 271 F.2d 492 (D.C. Cir, 1959), Kelly was applied to indecent liberties taken upon an eleven-year-old girl. Like a homosexual solicitation, this conduct is " $a$ phenomenon on the outer fringes of behavior." Kelly v. United States, 194 F.2d 150, 154 (D.C. Cir. 1952).

142 United States v. Kelly, 119 F. Supp. 217 (D.D.C. 1954).

143 Howard v. District of Columbia, 132 A.2d 150 (D.C. Munic. Ct. App. 1957). 144 Konvalinka v. United States, 162 A.2d 778 (D.C. Munic. Ct. App. 1960), aff'd per curiam, 287 F.2d 346 (D.C. Cir. 1961).

145 Wildeblood v. United States, 284 F. 2d 592, 598 (D.C. Cir. 1960) (separate opinion); Berneau v. United States, 188 A.2d 301 (D.C. Munic. Ct. App. 1963); Alexander v. United States, 187 A.2d 901 (D.C. Munic. Ct. App. 1963) ; Bicksler v. United States, 90 A.2d 233 (D.C. Munic. Ct. App. 1952); King v. United States, 90 A.2d 229 (D.C. Munic. Ct. App. 1952).

146 Guarro v. United States, 237 F.2d 578, 580 (D.C. Cir. 1956) ; see Seitner v. United States, 143 A.2d 101 (D.C. Munic. Ct. App.), aff'd per curian, 262 F.2d 710 (D.C. Cir. 1958). But see Dyson v. United States, 97 A.2d 135, 138 (D.C. Munic. Ct. App. 1953) (dissenting opinion). In Guarro, the court recognized that the Kelly rule applied both to assaults and to verbal communications since in an assault of this nature there would ordinarily be no physical traces or other witnesses. $237 \mathrm{~F} .2 \mathrm{~d}$ at 580. United States v. Kelly, 119 F. Supp. 217 (D.D.C. 1954), and Konvalinka v. United States, 162 A.2d 778 (D.C. Munic. Ct. App. 1960), aff'd per curiam, 287 F.2d 346 (D.C. Cir. 1961), assumed that Kelly applied to assaults and attempts without such reasoning.

147 237 F.2d 578, 582 (D.C. Cir. 1956).

148 Ibid. Other cases have not done so in opinions which indicate that the point was not even pressed. See Wildeblood v. United States, 284 F.2d 592 , 598 (D.C. Cir. 1960) (separate opinion); Seitner v. United States, 143 A.2d 101 (D.C. Munic. Ct. App.), aff'd per curiam, 262 F.2d 710 (D.C. Cir. 1958); Bicksler v. United States, 90 A.2d 233 (D.C. Munic. Ct. App. 1952); King v. United States, 90 A.2d 229 (D.C. Munic. Ct. App. 1952).

149187 A.2d 486 (D.C. Munic. Ct. App. 1963).

150 Id. at 488.

151 E.g., People v. Troutman, 187 Cal. 313, 201 Pac. 928 (1921) ; Commonwealth v. Allabaugh, $162 \mathrm{~Pa}$. Super. 490,58 A.2d 184 (1948).

152 E.g., People v. Sellers, 103 Cal. App. 2d 830, 230 P.2d 398 (Dist. Ct. App. 1951) ; People v. Bentley 102 Cal. App. 2d 97, 226 P.2d 669 (Dist. Ct. App. 1951).

153 In Reed v. United States, 93 A.2d 568 (D.C. Munic. Ct. App. 1953), vacated as moot, id. at 570 (per curiam), the court required the minimal corroboration that the defendant and the officer were present at the alleged time and place. 
"victim." ${ }^{154}$ Those courts unwilling to adopt strict corroboration requirements, therefore, can still follow Kelly, particularly if they attach significance to the sole witness' identity as a decoy policeman. Since no existing doctrine seems to enable a court to attach special significance to the decoy's testimony,155 a special "rule" for homosexual cases seems necessary. The development of a similar rule for hired informers and "stool pigeons" whose testimony may be colored by their financial stake in the conviction or by a promise of immunity has already begun. ${ }^{156}$

Either subconsciously ${ }^{157}$ or consciously a decoy policeman may mistake the facts. Although unsuccessful prosecutions should not affect his job security, they may enter into efficiency ratings and affect his chance of promotion. ${ }^{158}$ In addition, the policeman whose assignment is to find homosexuals may have a distorted impression of the subtle interchange which occurred, since he knows that he must fully justify his decision to make an arrest. ${ }^{159}$ In some cases a policeman may deliberately "frame" a homosexual for the purpose of blackmail ${ }^{160}$ or simply because of malice. ${ }^{161}$

154 More consummate offenses may be evidenced by medical examination results, see State v. Walhenmaier, 64 N.E.2d 148 (Ohio Ct. App. 1945) (sodomy), or by the testimony of eyewitnesses, see, e.g., United States v. Kelly, 119 F. Supp. 217 (D.D.C. 1954) (attempted sodomy); Commonwealth v. Donahue, $136 \mathrm{~Pa}$. Super. 306, 7 A.2d 13 (1939) (sodomy).

155 For example, the decoy cannot be deemed an accomplice whose testimony may require corroboration, e.g., MrNn. Stat. ANN. \$634.04 (1947); TEx. Code CrIm. Proc. art. 718 (1948), or particular caution, Freed v. United States, 266 Fed. 1021 (D.C. Cir. 1920); Williams, Corroboration-Accomplices, 1962 CRIM. L. Rev. (Eng.) 588. But see, e.g., Caminetti v. United States, 242 U.S. 470, 495 (1916); United States v. Becker, 62 F.2d 1007, 1009 (2d Cir. 1933). The reasons underlying the accomplice rule-that an accomplice may testify in a certain way in exchange for immunity, 7 WIGMORE, EvIDENCE $\$ 2057$ (3d ed. 1940); Williams, sipra at 589, 591; Note, 24 BrookLYN L. Rev. 324, 325 (1958), or because he desires revenge, Williams, supra at 588; Note, 24 BrookLYN L. REv. 324, 325 (1958), or wants to minimize his own responsibility, Williams, supra at 588-are inapplicable to a decoy situation. Texas follows the curious doctrine that entrapment requires corroboration of the decoy's testimony, rather than acquittal of the defendant, because the decoy is then considered an accomplice. See 9 Sw. L.J. 456, 466-71 (1955).

156 See On Lee v. United States, 343 U.S. 747, 757 (1952) (dictum); Fisher v. United States, 231 F.2d 99, 106 (9th Cir. 1956); Fletcher v. United States, 158 F.2d 321, 322 (D.C. Cir. 1946); United States v, Silva, 180 F. Supp. 557, 558 (S.D.N.Y. 1959); Donnelly, supra note 110 , at $1120-21$; Williams, supra note 155 , at 408 . But see United States v. Becker, 62 F.2d 1007, 1009 (2d Cir. 1933); cf. United States v. Troche, 213 F.2d 401 (2d Cir. 1954); United States v. On Lee, 201 F.2d 722 (2d Cir. 1953). Compare Williamson v. United States, 311 F.2d 441 (5th Cir. 1962) (contingent fee decoy is dirty business).

157 See Kubie, Implications for Legal Procedure of the Fallibility of Human Menrory, 108 U. PA. L. REv. 59, 60, 61, 67 (1959).

158 Donnelly, supra note 110, at 1119-20.

159 See Guarro v. United States, 237 F.2d 578, 581 (D.C. Cir. 1956); Goodsaid v. District of Columbia, 187 A.2d 486, 488 (D.C. Munic. Ct. App. 1962) ; Field Study 30 ; cf. Love v. People, 160 III. 501, 505, 43 N.E. 710 (1896) (private detective). Compare Field Study 23 (hostility of policemen to homosexual offenders).

160 See generally Cory, The Homosexuar in America 56, 433 (2d ed. 1960); Deutsch, The Trouble With Cops 76, 88-89 (1955); Mercer, They Walk iN SHADOw 352 (1959); Fonzi, The Furtive Fraternity, Greater Philadelphia, Dec. 1962, pp. 50-51; cf. State v. Mantes, 32 Idaho 724, 187 Pac. 268 (1920); 23 TuL. L. Rev. 399,402 (1949); 14 WASH. \& LEE L. REv. 88, 95 (1957).

161 ACLU, 37th Ann. Rep. 78 (1957); cf. Model Penal Code \$2.10, comment at 14 (Tent. Draft No. 9, 1959). 
Although courts often refuse to give the jury cautionary instructions about decoy'testimony, ${ }^{162}$ homosexual invitation cases are unique because of the possibility that the witness will misconstrue the implications of ambiguous language and conduct. ${ }^{163}$ Therefore, a court reluctant to apply special rules of caution either in a homosexual case or the ordinary decoy case might be willing to apply cautionary counsel when confronted with a case combining both a homosexual overture and a decoy. ${ }^{\mathbf{1 6 4}}$

\section{B. Resolution of the Credibility Contest}

After enunciating its three "counsels," the court in Kelly proceeded to apply them to the case at hand. It found that defendant's evidence of good character was impressive, that his explanation of his presence in the park and participation in the conversation was reasonable, that he knew his roommate was in the apartment at the time he allegedly invited the officer, and that the testimony of the officer was contradicted in one collateral respect by a disinterested witness. ${ }^{165}$ Ultimately, the court concluded that there was a reasonable doubt as to defendant's guilt and reversed for insufficient evidence. ${ }^{168}$

Later cases in the District of Columbia, although purporting to follow Kelly, have refused to reverse for insufficient evidence even when there was evidence of defendant's good character if his presence at the particular time and place was corroborated. ${ }^{167}$ Thus, the courts have reserved to

162 Compare Shettel v. United States, 113 F.2d 34 (D.C. Cir. 1940), and People v. Gardt, 258 I1l. 468, 101 N.E. 687 (1913), and State v. Showen, 60 Mont. 474, 199 Pac. 917 (1921), and State v. Black, 121 N.C. 578, 28 S. E. 518 (1897), and State v. Boner, 42 Wyo. 36, 288 Pac. 13 (1930), with On Lee v. United States, 343 U.S. 747, 757 (1952) (dictum), and Borck v. State, 39 So. 580 (Ala. 1905) (dictum), and State v. Showen, supra at 479-80, 199 Pac. at 919-20 (concurring opinion), and Kastner v. State, 58 Neb. 767, 79 N.W. 713 (1899), and State v. Love, 229 N.C. 99, 103-04, 47 S.E.2d 712, 715 (1948), and United States v. Phelps, 16 Philippine 410 (1900).

163 See Guarro v. United States, 237 F.2d 578, 581 (D.C. Cir. 1956); Field Study 30 .

104 Because of possible prejudice, homosexual defendants often waive jury trial. In such cases, although the cautionary counsels cannot be formalized in a jury charge, they should be reflected in the attitude of the trial judge.

165194 F.2d at 155-56. Compare James, Sufficiency of Evidence and Jury-Control Devices Available Before Verdict, 47 VA. L. REv. 218, 220 (1961):

The concept of sufficiency [in tort cases] . . has nothing to do with ordinary questions of credibility .... [However] courts do place outer bounds on credibility, and testimony which is ruled incredible as a matter of law will not be counted in determining sufficiency .... Courts have it in their power to extend the notion of incredibility as a matter of law so as to contract the jury's function substantially . . [But only in] an occasional extreme set of circumstances [will they go] beyond the physical facts situation . . . 166194 F.2d at 156.

167 Compare Wildeblood v. United States, 284 F.2d 592, 598 (D.C. Cir. 1960) (separate opinion), and Dyson v. United States, 97 A.2d 135 (D.C. Munic. Ct. App. 1953) (by implication), and Bicksler v. United States, 90 A.2d 233 (D.C. Munic. Ct. App. 1952), and King v. United States, 90 A.2d 229 (D.C. Munic. Ct. App. 1952), with Reed v. United States, 93 A.2d 568 (D.C. Munic. Ct. App. 1953), vacated as moot, id. at 570 (per curiam). Compare Moder PENAL CODE $\$ \$ 213.6(6), 251.3$ (Proposed Official Draft 1962) (testimony of the victim must be corroborated to prove deviate sexual intercourse by force or intimidation or committed upon a 
the trier of fact the larger part of the credibility question. ${ }^{168}$ These cases are compatible with the essential doctrine of Kelly that trial courts exercise caution in homosexual cases involving decoys. Although in one sense Kelly was an exercise of the normal appellate power to reverse for clear insufficiency of evidence, ${ }^{169}$ its cold-record evaluation of credibility by means of circumstantial evidence was an extraordinary exercise of that power. ${ }^{170}$ Rather than suggesting criteria and remanding for a new trial, the court in Kelly decided the case by actually applying the criteria to the facts before it in order to demonstrate a process and an attitude. ${ }^{171}$

According to Kelly, conviction for a prejudicial offense so easily charged and so hard to defend against should rest upon a firmer basis than merely the resolution of a credibility contest. Thus, the court sought whatever additional elements of proof it could find to aid the determination by the trier of fact. The elements it ultimately relied on, however, are of limited value. Evidence of defendant's good character is at most an imperfect safeguard. Many homosexuals who want to preserve their community standing lead a "double" life so that their friends and acquaintances will be unaware of their homosexuality. ${ }^{172}$ Similarly, the Kelly requirement of corroboration as to presence at the alleged time and place is a crude safeguard. Its introduction into evidence means relatively little, but its absence can be significant, especially since it is an easy requirement for the prosecution to fulfill. ${ }^{173}$ Thus, the most that a defendant can expect from the Kelly "counsels," aside from corroboration as to time and place, is an attitude of unusual caution by the trial court in evaluating the evidence. Once the trial judge as trier of fact or instructor of the

minor, but need not be corroborated for public solicitation); ModeL PeNAL CoDE $\$ 207.5$ (Tent. Draft No. 4, 1959) (same).

In Reed, the only prosecution evidence was the testimony of the decoy, and the defendant did not take the stand. The court considered it unimportant that the decoy's testimony was not thus contradicted. Compare Grant v. State, 69 Ga. App. 835 (1943) (conviction for soliciting prostitution may rest entirely on the decoy's testimony even though the accused does not take the stand). There is no mention of good character evidence in Wildeblood, and in Dyson bad character was proven by admissions of prior homosexual offenses. Good character evidence was introduced in Bicksler and King, but in Bicksler it was only of general good character rather than good character relevant to homosexuality.

168 King v. United States, supra note 167 , at 231 ; see Wildeblood v. United States, supra note 167; Bicksler v. United States, supra note 167.

169194 F.2d at 156 \& n.17.

170 The dissenting judge denounced the majority opinion as going beyond the bounds of appellate review and usurping the function of the jury on nothing more than a cold record. 194 F.2d at 156-57.

171 "We shall, for the present, refrain from imposing rigid requirements as to quantity or character of proof in these cases, but we call to the attention of trial courts certain considerations which we think should govern them in respect to these charges." 194 F.2d at 154.

172 Fonzi, supra note 160 , at $21,50-51$.

173 This requirement seems inconsistent with Kelly's purported notion of caution and counsel given by an appellate court to a trial court. However, $K e l l y$ purported to confine itself to caution and counsel because of reluctance to impose impossible burdens on the prosecution and this requirement is far from an impossible burden. Furthermore, this aspect of the case may explain reversal rather than remand for a new trial in Kelly. 
jury ${ }^{174}$ seeks to apply this attitude, the appellate court should exercise only its normal scope of review. ${ }^{175}$

There are other important elements of proof which Kelly did not consider. The court stressed the importance of defendant's good character evidence, which is normally shown by evidence of good reputation. ${ }^{178}$ Although the prosecution cannot initially introduce evidence of defendant's bad reputation, prior specific conduct, or prior offenses to indicate defendant's inclination to commit the crime, once defendant puts his character in issue evidence of his bad reputation is admissible in rebuttal. ${ }^{177}$ Even by taking the stand, the defendant may open the door for evidence of other crimes and even misconduct to impeach his credibility. ${ }^{178}$ Furthermore, some courts have permitted the prosecution initially to introduce evidence of similar sex offenses. ${ }^{179}$ Yet Kelly's particular concern with the risks of stigma and blackmail should preclude such evidence unless it pertains to prior convictions. ${ }^{180}$

Evidence of defendant's good character might also be expanded to include expert psychiatric testimony about his homosexual tendencies. ${ }^{181}$ Serious problems arise, however, with respect to both admissibility of individual opinion to show character and the reliability of the particular

174 Part of the background from which Kelly gathered its authority to prescribe "counsels" was Fletcher v. United States, 158 F.2d 321 (D.C. Cir. 1946), and Freed v. United States, 266 Fed. 1012 (D.C. Cir. 1920), where trial courts were reversed for failure to give cautionary instructions to the jury concerning the testimony of a paid drug addict informer and of an accomplice respectively. $194 \mathrm{~F} .2 \mathrm{~d}$ at 152.

Reversals are more likely to occur when there has been a jury trial below, not only because non-Kelly instructions will be obvious, but also because rules of caution about natural prejudices need be less severely applied when a judge rather than a jury is the trier of fact. Moreover, it cannot be expected that a trial judge will articulate the fact-finding processes as fully when he is the trier of fact as when he is instructing the jury how to evaluate the conflicting evidence. $16 \mathrm{CAN}$. B. REv. 572, 575 (1938) ; see United States v. Perkins, 190 F.2d 49 (7th Cir. 1951) ; cf. Ott v. Board of Registration in Medicine, 276 Mass. 566, 177 N.E. 542 (1931). Futhermore, because of a jury's greater susceptibility to prejudice, the Kelly considerations might be more severely applied in jury cases than in non-jury cases like Kelly.

175 See Wildeblood v. United States, 284 F.2d 592, 594, 598 (D.C. Cir. 1960) (separate opinion); Bicksler v. United States, 90 A.2d 233 (D.C. Munic. Ct. App. 1953) ; King v. United States, 90 A.2d 229 (D.C. Munic. Ct. App. 1953); State v. Vicknair, 103 La. 1921, 28 So. 273 (1900); 6 Res Judrcatae 538, 539 (1954).

178 McCormick, Evmence \$158, at 334-35 (1954).

177 See McCormrck, Evinence $\$ 157$, at 327 (1954); id. \$158. Defendants in homosexual cases may also be able to introduce the fact that they are married and have children. State v. Sinnott, 24 N.J. 408, 416, 132 A.2d 298, 302 (1957). In any event, such evidence can be introduced indirectly. See King v. United States, 90 A.2d 229, 230 (D.C. Munic. Ct. App. 1953) (defendant's steady girl friend was character witness).

178 See note 116 supra.

179 Ibid.

180 But see Dyson v. United States, 97 A.2d 135 (D.C. Munic. Ct. App. 1953), which allowed admissions of prior offenses in a decoy homosexual assault case without considering whether admissibility was in harmony with Kelly.

181 In Konvalinka v. United States, 162 A.2d 778, 780 (D.C. Munic. Ct. App. 1960), aff'd, 287 F.2d 346 (D.C. Cir. 1961), psychiatric testimony was admitted, but its admissibility was not contested on appeal. 
method of psychiatric examination. ${ }^{182}$ Although cases involving the actual commission of sodomy have rejected psychiatric testimony on both of these grounds, ${ }^{183}$ the special need for further evidence in homosexual overture cases due to a paucity of objective elements of proof might argue for their admissibility. The individual opinion problem can be resolved in favor of admissibility in these cases, ${ }^{184}$ especially if the prosecution is also permitted to answer with its own or independent experts. ${ }^{185}$ If the defendant has not put character in issue, the prosecution's introduction of psychiatric testimony in order to prove homosexual tendencies raises essentially the same questions as the admissibility of prior offenses. However, psychiatric testimony is fairer to a defendant than proof of prior offenses because it recognizes the possibility of his subsequent reform. But it is also more prejudicial because the trier of fact may convict by a "bad man bad act" inference, or infer from the expert's testimony that the defendant should be isolated from society or be subject to psychiatric treatment regardless of the crime charged. ${ }^{186}$

182 Compare People v. Jones, 42 Cal. 2d 219, 266 P.2d 38 (1954) (disapproving People v. Sellers, 103 Cal. App. 2d 830, 230 P.2d 398 (Dist. Ct. App. 1951), and relying in part on statutes relating to the treatment of sexual psychopaths), and Curran, Expert Psychiatric Evidence of Personality Traits, 103 U. PA. L. Rev. 999 (1955), and 42 Calif. L. Rev. 880 (1954), and 12 Rutgers L. Rev. 410 (1957), with State v. Sinnott, 24 N.J. 408, 132 A.2d 298 (1957), and Falknor \& Steffen, Evidence of Character: From the "Crucible of the Community" to the "Couch of the Psychiatrist," 102 U. PA. L. REv. 980 (1954).

183 People v. Sellers, supra note 182, State v. Sinnott, supra note 182.

184 The reliability of the psychiatric examination presents problems. See People v. Jones, 42 Cal. 2d 219, 225, 266 P.2d 38, 42-43 (1954); State v. Sinnott, 24 N.J. 408, 421-24, 427-28, 132 A.2d 298, 305-07, 309-10 (1957); State v. Lindemuth, 56 N.M. 257, 271-74, 243 P.2d 325, 334-36 (1952) ; Curran, snepra note 182, at 1014-19; Dession, Freedman, Donnelly \& Redlich, Drug-Induced Revelation and Criminal Investigation, 62 YALE L.J. 315 (1953) ; Macdonald, Truth Serum, 46 J. CRIM. L., C. \& P.S. 259 (1955) ; Muehlberger, Interrogation Under Drug Infulence, 42 J. CRIM. L., C. \& P.S. 513, 525-26 (1951) ; 42 CALIF. L. Rev. 880, 884 (1954); 12 Rutgers L. REv. 410, 413 (1957).

185 See State v. Sinnott, supra note 184, at 430,132 A.2d at 310; Curran, supra note 182, at 1010-12; Falknor \& Steffen, supra note 182, at 990-91; 12 RuTGERs L. REv. 410, 412-13 (1957). Concern that introduction of the state's expert testimony in rebuttal will develop into a battle of the experts has led to the suggestion that defendants not introduce psychiatric testimony. See State v. Sinnott, supra at 430 , 132 A.2d at 310-11; 12 Rutgers L. Rev. 410, 413 (1958). A further complication is the possibility of due process and self-incrimination problems when the defendant is compelled to submit to a psychiatric examination on an issue probative of guilt. See generally Townsend v. Sain, 372 U.S. 293, 307-09 (1963); Silving, Testing of the Unconscious in Criminal Cases, 69 HaRv. L. Rev. 683 (1956); 8 UTAH L. Rev. 141 (1962). Falknor \& Steffen, supra note 182, at 990-91, suggests that the state could introduce psychiatric testimony even if the defendant introduced evidence of his good reputation in the traditional manner. In People v. Giani, 145 Cal. App. 2d 539, 302 P.2d 813 (Dist. Ct. App. 1956), the state was not permitted to adduce defendant's admission that he was a homosexual because it did not raise enough of a probability that he committed the act in question. However, defendant's admission of specific prior homosexual acts were held admissible in Dyson v. United States, 97 A.2d 135 (D.C. Munic. Ct. App. 1953).

186 See Curran, supra note 182, at 1010-11. For an indication of the extent to which juries will be influenced by the testimony of the psychiatrist, see James, Juror's Evaluation of Expert Psychiatric Testimony, 21 Онго ST. L.J. 75 (1960). This study deals with testimony on the issue of criminal responsibility and therefore its suggestion that jurors are not likely to be influenced by the expert in their ultimate conclusions, $i d$. at 95 , may be of limited value when the issue is whether the defendant committed the crime. 
Whereas in Kelly defendant denied that he had engaged in the prohibited conduct, in Seitner $v$. United States, ${ }^{187}$ defendant admitted the touching in an assault case but claimed that the officer consented. The only evidence on the issue was the conflicting testimony of the defendant and the plainclothsman. The court held that Kelly did not require corroboration of the lack of consent. ${ }^{188}$

Concededly, both the Kelly "counsels" and the additional elements of proof suggested in this Note are not helpful on the issue of consent. But if the officer is mistaken or testifies falsely about his own apparent consent, defendant must then engage in a Kelly-type credibility contest. Although a corroboration requirement for lack of apparent consent would make prosecution for the touching virtually impossible, an attitude of unusual caution could still prevail. This attitude, however, would be virtually unreviewable. Similarly, the Kelly "counsels" are not helpful when any other defense based upon the decoy's conduct is claimed, ${ }^{189}$ although an attitude of caution would still seem to be necessary.

The court in Kelly appeared especially concerned with the effect of conviction on the defendant's standing in the community. However, since these collateral effects are less harmful to the defendant who actually admits homosexual conduct, an attitude of caution is not essential when a defense is based on the decoy's conduct. ${ }^{190}$ However, when entrapment is claimed, caution should be required since the concern is no longer solely with conviction and its collateral effects but also with abuse of law enforcement processes upon situational offenders.

187143 A.2d 101 (D.C. Munic. Ct. App. 1958), aff'd per curiam, 262 F.2d 710 (D.C. Cir. 1958).

188 The defendant argued before the circuit court of appeals that his conviction should be reversed on the authority of Guarro v. United States, 237 F.2d 578 (D.C. Cir. 1956) (consent a defense to the assault consisting of homosexual touching). However, the municipal court of appeals committed no error with respect to the application of the legal rule of Guarro; the error, if any, was failure to use Kelly caution in finding the necessary facts for the application of that rule. Guarro was no help to the defendant since the court in Guarro stated that the facts relevant to the consent issue in that case were not disputed. Guarro v. United States, sipra at 581.

189 If predisposition is relevant in entrapment, then bad character and expert psychiatric testimony remain important elements of proof.

190 The defendant may make alternative claims that he did not commit the offense, but that if he did, the officer's conduct vitiated it. Compare Day v. United States, 148 A.2d 462, 463 (D.C. Munic. Ct. App. 1959), and Dyson v. United States, 97 A.2d 135, 137 (D.C. Munic. Ct. App. 1953), with Gorin v. United States, 313 F.2d 641, 654 n.10 (1st Cir. 1963), cert. denied, 374 U.S. 829 (1963), and Hansford v. United States, 303 F.2d 219, 221 (D.C. Cir. 1963), and 70 HaRv. L. Rnv. 1302, 1303 (1957). However, his testimony may not cover both claims. Sylvia v. United States, 312 F.2d 145 (1st Cir. 1963), cert. denied, 374 U.S. 809 (1963); 70 HARv. L. REv. 1302, 1303 (1957); see Marko v. United States, 314 F.2d 595 (5th Cir. 1963). If he pleads in the alternative but his testimony covers only one claim, the jury should receive a cautionary charge from the trial court even though the officer's testimony which contradicts the defendant's unsupported plea is not contradicted by other evidence. Cf. Reed v. United States, 93 A.2d 568 (D.C. Munic. Ct. App. 1953), vacated as moot, id. at 570 (per curiam). 


\section{CONCLUSION}

Even if the statutory objectives to deter more consummate crime and prevent annoyances to the public are served by the use of decoys to harass without actual prosecutions, ${ }^{191}$ some prosecutions are necessary to provide judicial supervision of police practices. ${ }^{192}$ When prosecutions do occur, the distinction between innocent conversation and homosexual overtures requires unusually close attention to the factual situation. The task of finding criminality in more provocative behavior or touching is not as difficult. However, in all homosexual overture offenses involving decoys the court must determine criminality on the basis of the conduct of both the defendant and the decoy. Unless the police use scientific evidence-gathering devices, the inherent limitations of the ordinary testimonial evidence complicates the problem further. ${ }^{193}$ Nevertheless, courts must not allow the pressures of the practical situation to result in the virtual elimination of legitimate defenses, since this approach would expand the statutes to condemn homosexual tendencies. On the other hand, decoys are the only practicable means of enforcing homosexuality statutes. Therefore, if unfounded defenses based on the activity of decoys become increasingly successful, the statutes themselves will become ineffective.

Harold Jacobs $\dagger$

191 See note 19 supra.

192 See Goldstein, Police Discretion Not To Invoke the Criminal Process: Low Visibility Decisions in the Administration of Justice, 69 Y ALE L.J. 543, 580-81 (1960); cf. National Comm'n on Law Observance and Enforcement, Report on LawLESSNESS IN LAW ENFORCEMENT 1-10 (1931); Foote, Law and Police Practices: Safeguards in the Laze of Arrest, 52 Nw. U.L. Rev. 16, 19 (1957). The limited availability of tort claims for false arrest, see, e.g., Foote, Tort Remedies for Police Violations of Individual Rights, 39 MINN. L. REv. 493, 500-01 (1955), is further accentuated in homosexual offenses by the risk that social stigma may attach to anyone who is even accused of such an offense.

193 For example, the decoy could carry a device to record the conversation or to broadcast it to another police officer located nearby who could arrive immediately to identify the voice. Cf. People v. Lewis, 214 Cal. App. 2d 856, 29 Cal. Rptr. 825 (Dist. Ct. App. 1963) (decoy with miniature radio transmitter in house of prostitution); People v. Hornbeck, 277 App. Div. 1136, 101 N.Y.S.2d 182, 184 (1950) (dictum) (sound recording of admission over telephone sufficient to corroborate testimony of rape prosecutrix).

† LL.B. 1963, University of Pennsylvania. Editor, Volumes 109, 111. 